trolling convulsions due to tricyclic antidepressant poisoning. This suggestion was made on the basis of the beneficial use of this drug "in two children and two young adults poisoned with amitriptyline." The effectiveness of diphenylhydantoin in this situation has never been clearly substantiated either in the laboratory or in clinical practice.

Recently we have been investigating the effectiveness and safety of various anticonvulsants in the prophylaxis of imipramine-induced convulsions in rats. We found that diphenylhydantoin in intraperitoneal doses ranging from 5 to $200 \mathrm{mg}$ / $\mathrm{kg}$ failed to prevent convulsions brought about by intraperitoneal administration of imipramine $112 \mathrm{mg} / \mathrm{kg}$. This was in contrast to the high anticonvulsant effectiveness of diazepam or phenobarbital in similar experiments.

This observed ineffectiveness of diphenylhydantoin in controlling imipramine seizures in rats is not surprising, since an important factor in the use of this drug as an "anticonvulsant" is the aetiology of the convulsions. For example, diphenylhydantoin does not control febrile convulsions in children under 3 years of age $^{1}$ nor is it effective in the treatment of seizures associated with barbiturate withdrawal. ${ }^{2}$ Moreover, diphenylhydantoin does not raise the threshold to minimal electroshock seizure or prevent pentylenetetrazol-induced convulsions. $^{3}$ Our experiments suggest that dipenylhydantoin may not have any value as an anticonvulsant in the therapy of tricyclic antidepressant poisoning. However, this does not exclude the possibility that diphenylhydantoin may have a use in controlling the cardiac arrhythmias associated with tricyclic antidepressant overdose.-We are, etc.,

\section{C. Carpenter}

A. R. BEAUBIEN

Health Protection Branch,
Department of National Health and Welfare,

L. F. MATHIEU

P. D. HRDINA

Department of Pharmacology,

University of Ottawa Medical School,
Ottawa, Canada

1 Melchior, J. C.. Buchthal, F., and LennoxBuchthal, M., Epilepsia, 1971, 12, 55.

2 Essig, C. F. Ep. Epilepsia, 1967, 8, 21. Therapeutics, ed. L. S. Goodman and A Gilman, 4th edn., p. 208. New York, Macmillan

\section{Mycoplasma Pneumonia with Inappropriate} Secretion of Antidiuretic Hormone

SIR,-We were interested to read the report by Drs. A. Spanos and C. J. Spry (28 September, p. 785) of inappropriate secretion of antidiuretic hormone $(\mathrm{ADH})$ in a patient with chronic bronchitis. We describe here the same phenomenon in a child with bronchopneumonia due to Mycoplasma pneumoniae.

A 6-year-old boy was admitted with a five-day history of a febrile illness associated with headache, anorexia, abdominal pain, and a harsh unproductive cough. He had been treated at home with ampicillin for $24 \mathrm{~h}$. On admission he had a temperature of $39^{\circ} \mathrm{C}$ and a harsh cough. A few crepitations wer heard at both lung bases and the chest $x$-ray showed consolidation in both lower lobes. The haemoglobin was $13 \mathrm{~g} / \mathrm{dl}$, W.B.C. $5 \cdot 8 \times 10^{9} / 1$ $\left(5800 / \mathrm{mm}^{3}\right)$, and E.S.R. $12 \mathrm{~mm}$ in $1 \mathrm{~h}$. The complement fixation test for mycoplasma was negative at first but the titre rose to $1 / 1024$ after four weeks.
Ampicillin was continued intramuscularly but had to be withdrawn after two days when the patient developed a generalized urticarial rash Cephalexin was substituted but in spite of this his fever persisted for eight days after admission. On the fifth hospital day he was noticed to be drows and irritable with a poor fluid intake. His serum electrolytes and blood urea were: sodium $125 \mathrm{mmo}$ $(\mathrm{mEq}) / \mathrm{l}$, potassium $2 \cdot 8 \mathrm{mmol}(\mathrm{mEq}) / 1$, chloride $88 \mathrm{mmol}(\mathrm{mEq}) / 1$, bicarbonate $28 \mathrm{mmol}(\mathrm{mEq}) / 1$ and urea $3.7 \mathrm{mmol} / 1(22 \mathrm{mg} / 100 \mathrm{ml})$. The plasma osmolality was $265 \mathrm{mmol}(\mathrm{mOsm}) / \mathrm{kg}$ and the urine
osmolality was $613 \mathrm{mmol}(\mathrm{mOsm}) / \mathrm{kg}$. Unfortunately ADH measurements were not available. His fluid intake was restricted to $500 \mathrm{ml}$ daily and on this his condition gradually improved. The and on this his condition gradually improved. The $\mathrm{h}$, as did the osmolality of his serum and urine. His $\mathrm{h}$, as did the osmolality of his serum and urine. His 10 days and his chest $x$-ray was completely clear two weeks later.

Inappropriate secretion of $\mathrm{ADH}$ has been described in association with both acute and chronic chest infection in adults ${ }^{12}$ but we believe this to be the first report of its occurrence in association with $M y c$. pneu moniae infection or in a child with acute pneumonia. The source of $\mathrm{ADH}$ in these patients is unknown; tumours of the lung may produce the hormone, as may tuberculous lung tissue, ${ }^{3}$ and it has been suggested that hypoxia and low cardiac output may act as a stimulus to $\mathrm{ADH}$ production.

It is also possible that excessive $A D H$ secretion is a non-specific response to stress, and it would be of interest to investigate this possibility in patients subjected to othe forms of stress such as major injury or surgery.-We are, etc.

T. M. LITTLE

Department of Child Health,

Department of Child Health,
University Hospital of Wales,
Cardiff

R. H. DOWDLE

Rosenow, E. C., Segar, W. E., and Zehr, J. E. Mayo Clinic Proceed

Spanos, A., and Spry, C. J., British Medical Vorherr, H., et al., Annals of Internal Medicine, $1970,72,383$

Henry, J. P., Gaurer, O. H., and Reeves, J. L. Circulation Research, 1956, 4, 85

5 Myers, J. B., British Medical fournal, 1974, 4

Fatality after Fine-needle Aspiration Biopsy of Liver

SIR,-Fine-needle aspiration biopsy of the liver is considered a safe procedure. Over haemorrhagic diathesis is considered the only absolute contraindication. ${ }^{1}$ Open liver biopsy, on the other hand, is associated with a definite risk. We wish to report a case of death after a fine-needle aspiration biopsy.

A 62-year-old man, who had had a portocaval end-to-side shunt operation and splenectomy in 1973 for cryptogenic liver cirrhosis associated with bleeding oesophageal varices, splenomegaly, and

thrombocytopenia, was admitted to hospital in September 1974 with impending hepatic coma. His blood ammonia was $165 \mu \mathrm{mol} / \mathrm{l}(231 \mu \mathrm{g} / 100 \mathrm{ml})$ normal range 28-64 $\mu \mathrm{mol} / \mathrm{l}$ ) and total serum bilirubin $213 \mu \mathrm{mol} / 1(12.5 \mathrm{mg} / 100 \mathrm{ml}$ ) (normal range $5-20 \mu \mathrm{mol} / \mathrm{l}$ ). About $90 \%$ of the bilirubin was conjugated. The coarse nodularity of the liver w edge, palpable some $5 \mathrm{~cm}$ below the costal margin, seemed to increase during the patient's stay in hospital. An uneven uptake of labelled isotope on liver scanning was compatible with cirotope on iver scanning was compatible with cirrhosis but $\subseteq$ did not exclude malignancy. Alphafetoprotein was not present. Bleeding and coagulation times were Thrombotest value $31 \%$. Because of suspected $\bar{O}$ malignancy a fine-needle aspiration biopsy of the malignancy a fine-needle aspiration biopsy of the liver was performed with a $0.7 \times 100 \mathrm{~mm}$ needle by a person familiar with the procedure. A subcostal approach was used. The patient experienced $\mathbb{\Phi}$ no untoward symptoms. A diagnosis of hepatocelluEight hours after the aspiration signs of shock developed and intra-abdominal bleeding was $\overrightarrow{0}$ diagnosed. Despite treatment the patient died two days later. At necropsy the abdomen contained $\vec{\omega}$ about a litre of blood. The biopsy needle had $\omega$ passed through a necrotic tumour about $5 \mathrm{~cm}$ in diameter and had emerged on the dorsal aspect of the liver surface. Blood clots covered both the entrance and exit sites of the needle in the liver. bouring structures. The liver was severely cirrhotic and contained many cancerous areas.

Fine-needle aspiration biopsy of the liver i has been considered virtually risk-free. In this patient with liver cirrhosis associated 음 with a primary hepatoma, however, the procedure, though correctly executed, led to $>$ gross intra-abdominal haemorrhage and, in conjunction with other factors, to the death $\frac{\rho}{工}$ of the patient.-We are, etc.,

Fourth Department of Medicine,

HENRIK RISKA ò Claes Friman

niversity of Helsinki,

Helsinki, Finland

öderström, N., in Fine-needle Aspiration Biopsy.

\section{Abortion Service}

SIR,-I am not concerned to defend or attack the book reviewed under the above heading (8 February, p. 340). But your reviewers should not be allowed to get away with the suggestion plainly implicit in their final paragraph that those who argue from a moral point of view against abortion have no compassionate view of the circumstances of the mother. It is quite untrue. A very 0 considerable number of people do, however, consider that the fetus has rights to life and $N$ that at the least the Abortion Act should be $D$ tightened so that those rights are not overridden without very serious consideration. And Parliament has taken note of that feeling.-I am, etc.,

E. D. IRVINE

Exeter

\section{Owen Working Party}

SIR,-The B.M.A.'s account of the proceedings in the Owen Working Party (4 January, p. 48) and of subsequent events has not answered all the questions the thoughtful doctor would like to ask. I am therefore writing on behalf of the executive committee of the Association of University Clinical Academic Staff to clarify certain points. Our information on proceedings of the Owen Working Party is derived from discussions with eight of its members.

At the final meeting of the Owen Working Party on 20 December, our negotiators responded with heat to Mrs. Castle's ahair- $\frac{\overrightarrow{+}}{\mathbb{D}}$ manship. She had introduced the Depart- $\Omega$ ment of Health and Social Security's pro- $\mathbb{Q}$ posals on a new consultant contract by $\sigma$ saying that they had been prepared at short notice, under pressure from the profession, and she wanted our negotiators to take them away for further discussion with their colleagues. Our negotiators became upset. At $\stackrel{一}{\supsetneq}$ one stage they asked if the proposals represented a "take it or leave it" offer and were told that the principles were not negotiable, though the details were. Exchanges became 